\title{
Quality of the household ozone laundering
}

DOI: $10.35530 / I T .069 .04 .1454$

\section{REZUMAT - ABSTRACT}

\section{Calitatea spălării casnice cu ozon}

În cadrul acestui studiu au fost investigate diferite proceduri de spălare casnică. După efectuarea procedurilor combinate clasice și cu ozon, au fost evaluate efectele de spălare primară și secundară, cum ar fi performanța de spălare, eficiența eliminării murdăriei, modificarea dimensională, scăderea rezistenței la rupere, reziduurile de incinerare și caracteristicile de culoare. Rezultatele finale au indicat faptul că spălarea casnică cu ozon oferă o calitate superioară a spălării în comparație cu procedura clasică și asigură reducerea consumului de apă și de energie.

Cuvinte-cheie: ozon, spălarea materialelor textile, mașină de spălat de uz casnic, generator de ozon, efecte de spălare

\section{Quality of the household ozone laundering}

Different household laundering procedures were investigated in this research. After performing classical and with ozone combined procedures, the primary and secondary laundering effects were evaluated, as washing performance, soil removal efficiency, dimensional change, decrease in breaking strength, incineration residue and colour characteristics. The end results indicate that household ozone laundering provides higher laundering quality compared to the classical procedure, and ensures reduction of water and energy consumption.

Keywords: ozone, textile laundering, household washing machine, ozone generator, laundering effects

\section{INTRODUCTION}

The main purpose for textile laundering is the removal of impurities, unpleasant odours and microorganisms, but with consideration that, at the same time, the fabric surface or structure must remain undamaged as much as possible. Household laundering is a complex process, where the synergy of physical and chemical factors in the aqueous medium influence the final results of textile cleaning. According to Sinner, the factors which determine the laundering quality are: chemical action, mechanical action, temperature and time. There is also a fifth quality parameter, water, which was added by Stamminger later, in order to expose its significance [1]. Water enables wetting with superseding air from fibres; it is a transportation system for heat and kinetic energy, a dispersing agent which, with help of detergent, absorbs inorganic and organic impurities and micro-organisms, thus preventing their re-deposition onto a textile's surface or onto parts of the washing machine [2-3].

Textile laundering is the most frequent household occupation, important to assure hygiene, reduce infection risk and, thus, protect the health and safety of household members. In the last decade, significant improvements in energy efficiency and also energy consumption have been achieved in home appliances. But, annual statistics and studies reveal a further wasteful consumption of water and energy in the EU27 household sector, where, amongst the largest energy consumers are washing machines [4-7].

Heightened environmental legislation demands producers to focus on the application and development of new textile care technologies and processes for household laundering machines. The introduction of ozone in the industrial laundries has increased significantly in the last decades. Yet, on the other hand, the use of ozone for textile washing is still almost unknown. In the past, rare research reports have been published referring to industrial ozone laundering. Reports expose mainly the economic benefits, such as water, energy, chemicals and detergents reduction and the disinfection effects [8-11]. At the same time, in published reports, there have been no results referring to primary and secondary laundering effects and related laundering quality.

This paper evaluates the influences of classical and newly developed household ozone laundering procedures on the laundering quality using a household washing machine and ozone-generator. The first goal was to examine and evaluate the soil removal efficiency of each laundering procedure. After analysing the acquired results, there followed a selection of the most appropriate ozone procedure based on the efficiency and environmental impact factors. The next goal was to carry out and evaluate the influence of laundering repetitions on the properties of fabrics. After 25 laundering cycles (classical or with addition of ozone) of standard cotton fabrics, the secondary laundering effects were determined: Dimensional change, decrease in breaking strength, incineration residue and colour characteristics. All parameters (duration, water, electricity) were collected and analysed of each examined laundering procedure. 


\section{EXPERIMENTAL PART}

The one-bath household classical and two-bath ozone laundering procedures were performed with the aim of evaluating the soil removal efficiency and the impacts on the fabric's properties. The primary and secondary effects were determined under laboratory conditions. A household washing machine, ozone-generator, ballast fabrics, stain test strips, standard fabrics and detergent were used. The laundering effects were measured and evaluated in accordance with ISO, EN, SIST or CIE requirements, specifications or guidelines. All experiments were repeated three times.

\section{Materials}

In the research of primary laundering effects, we used $4.5 \mathrm{~kg}$ of ballast load (consisting of cotton sheets IEC T11, pillow cases IEC T13 and towels IEC T12), and stain strips. The characteristics of the stains used for evaluation of soil removal efficiency are presented in table 1. When secondary laundering effects were determined, two pieces of standard cotton fabrics (SC) [12] (100\% cotton, 295 dtex in warp and weft direction, $170 \mathrm{~g} / \mathrm{m}^{2}$, plain wave) and ballast load were laundered 25 times.

In the main-washing phases of all laundering procedures the IEC 60456 standard detergent $A^{*}$ was added, composed of $77 \%$ basic powder, $20 \%$ bleaching agent Sodium Perborate Tetrahydrate (SPT) and $3 \%$ bleach activator (TAED). The main ingredients of the basic powder are: Surfactants for soil removal (linear sodium alkyl benzene sulfonate, ethoxylated fatty alcohol $\mathrm{C}_{12 / 14}(7 \mathrm{EO})$, sodium soap), scale inhibitors (phosphonate Dequest 2066 (diethylenetriamine penta (methylenephosphonic) acid, sodium salt, sodium chloride), sodium aluminium silicate zeolite 4A), sodium carbonate, sodium sulphate, carboxymethyl cellulose and anti-redeposition agent, coagulant sodium silicate, enzyme protease (hydrolysing insoluble protein stains into soluble peptides and amino acids, which can be removed from fabrics easily already at $20-40{ }^{\circ} \mathrm{C}$ ) and stilbene type optical whitener.

All used textile materials and laundering detergents were supplied from WFK Testgewebe $\mathrm{GmbH}$ (D).

The characteristics of the ballast load, SC fabrics, stain strips and amounts of added laundering detergent meet the Standards [12-13].

\section{Laundry equipment and procedures}

In our research, five different laundering procedures were carried out. Their structure, regarding laundering phases' sequences, laundering temperatures, amounts of detergent and added ozone, are shown in table 2. The first procedure was a classical (CL) laundering procedure consisting of main-washing at $40^{\circ} \mathrm{C}$, two phases of rinsing with cold water, and final spinning $\left(1200 \mathrm{rpm}^{-1}\right)$. It followed two procedures where ozone was added to the inlet water. During the latter procedure $\left(\mathrm{CO}_{\mathrm{MR}}\right)$, ozone was added in the main-washing and rinsing phases, and in the third performed laundering procedure $\mathrm{CO}_{\mathrm{RI}}$ ozone was added only in two rinsing phases. The laundering temperatures $\left(40^{\circ}\right)$ and spinning conditions (1200 $\mathrm{rpm}^{-1}$ ) were equal in both cases.

Two-bath ozone procedures were also performed in the scope of the first part of the research. They con-

Table 1

\begin{tabular}{|l|l|c|c|c|c|c|}
\hline \multirow{2}{*}{ Soil type } & \multicolumn{1}{|c|}{ Composition of soil [13] } & \multicolumn{5}{|c|}{ Colour Characteristics CIELAB (D65/10) } \\
\cline { 3 - 7 } & \multicolumn{1}{|c|}{} & $\boldsymbol{R}_{\mathbf{4 6 0}}$ & $\boldsymbol{Y}$ & $\boldsymbol{L}^{*}$ & $\boldsymbol{C}^{*}$ & $\boldsymbol{h}$ \\
\hline Unsoiled & $100 \%$ cotton, 200 $\mathrm{g} \cdot \mathrm{m}^{2}$, desized, scoured, calandered & 80.90 & 81.46 & 92.34 & 1.17 & 111.16 \\
\hline Sebum & $\begin{array}{l}\text { Cows' and wool fat, free fatty acid, cholesterol, squalen, } \\
\text { coconut oil, hard paraffin, carbon black, kaoline, iron oxide }\end{array}$ & 47.21 & 49.35 & 75.56 & 2.99 & 97.60 \\
\hline Carbon & Carbon black, paraffin oil & 20.81 & 22.01 & 53.98 & 2.53 & 74.47 \\
\hline Blood & Fresh pig's blood, stabilised with ammonium citrate & 16.65 & 21.88 & 53.88 & 17.99 & 57.06 \\
\hline Cocoa & Unsweet. cocoa (22 \% fat), sugar, full-cream cow's milk, water & 22.81 & 33.75 & 64.76 & 21.05 & 58.05 \\
\hline Red wine & Red wine, treated with hot air & 39.23 & 40.74 & 69.99 & 12.18 & 11.37 \\
\hline
\end{tabular}

Table 2

\begin{tabular}{|c|c|c|c|c|c|c|c|c|c|}
\hline \multirow{2}{*}{$\begin{array}{l}\text { Proc. } \\
\text { code }\end{array}$} & \multicolumn{2}{|c|}{ Pre-washing } & \multicolumn{3}{|c|}{ Main-washing } & \multicolumn{2}{|c|}{ Rinsing 1} & \multicolumn{2}{|c|}{ Rinsing 2} \\
\hline & $\mathrm{Oz}$ & $\mathbf{T}$ & Det & $\mathrm{Oz}$ & $T$ & $\mathrm{Oz}$ & $T$ & $\mathrm{Oz}$ & $T$ \\
\hline $\mathrm{CL}$ & - & - & 94 & - & 40 & - & Col & - & Col \\
\hline $\mathrm{CO}_{\mathrm{MR}}$ & - & - & 94 & 1 & 40 & 1 & Col & 1 & $\mathrm{Col}$ \\
\hline $\mathrm{CO}_{\mathrm{RI}}$ & - & - & 94 & - & 40 & 1 & Col & 1 & Col \\
\hline $\mathrm{PO}_{30}$ & 1 & 30 & 94 & - & 30 & 1 & Col & - & 一 \\
\hline $\mathrm{PO}_{40}$ & 1 & 30 & 94 & - & 40 & 1 & Col & - & - \\
\hline
\end{tabular}

Note: Det - Laundering detergent IEC A (94g/cycle), Oz - Ozone (1 mg/L), T - Laundering temperature $\left({ }^{\circ} \mathrm{C}\right)$,

Col - Rinsing with a cold water 
sisted of four phases: Pre-washing in a laundering bath heated to $30^{\circ}$ with the addition of ozone, mainwashing, cold rinsing with added ozone and final spinning $\left(1200 \mathrm{rpm}^{-1}\right)$. In the case of a two-bath ozone procedure, $\mathrm{PO}_{30}$, the main-washing laundering bath was heated to $30^{\circ} \mathrm{C}$, and, in case of the $\mathrm{PO}_{40}$ procedure, it was heated to $40^{\circ} \mathrm{C}$.

During the second part of the research, evaluation of secondary laundering effects was carried out only on two laundering procedures. Initially, 25 cycles of the classical procedure CL were performed, followed by 25 cycles of the two-bath ozone procedure $\mathrm{PO}_{40}$. The structures and the conditions of 25 times performed washing procedures $\mathrm{CL}$ and $\mathrm{PO}_{40}$ were identical to those in the first part of the research (table 2).

All laundering procedures were performed in a household washing machine SensoCare W8665K Gorenje d.d. (SLO), with a capacity of $9.0 \mathrm{~kg}$ and a drum volume of $64 \mathrm{~L}$. The inlet water characteristics met the Standard [13]: conductivity $<10 \mu \mathrm{S} / \mathrm{cm}$, total water hardness $2.5 \pm 0.2 \mathrm{mmol} / \mathrm{L}, \mathrm{pH}=7.3-7.7$, $\mathrm{T}=15 \pm 2^{\circ} \mathrm{C}$.

Ozone was generated with a commercial ozone-generator OVK-W01 Eco Laundry $(\mathrm{CN})$ at room atmosphere. In the laundering procedures, a concentration of $1.0 \mathrm{mg} / \mathrm{L}$ of ozone was used with a water flow rate of $4.5 \mathrm{~L} / \mathrm{min}$. Ozone is produced under the corona discharge principle. The surrounding air is pumped through the filter into the oxidizing module with a very strong electric field. That splits the molecules of oxygen into highly excited negatively charged oxygen atoms which react with other unstable oxygen molecules and, thus, form highly reactive and chemically unstable ozone gas [14-15]. The produced ozone is injected into water under negative pressure, which is generated in a venture injector, pulling the ozone into the inlet water stream [16].

The amounts of water, as well as their temperatures, total water hardness, conductivity and $\mathrm{pH}$ values, were measured using digital meters, WFH36 DVN Qvedis $\mathrm{GmbH}$ (D), at the inlet pipes. Power consumption was measured using an EMU Check electricity metre, EMU Elektronik AG $(\mathrm{CH})$.

\section{Determination of primary laundering effects - soil removal efficiency}

Non-laundered and laundered stain strips were measured with the spectrophotometer Datacolor SF600 $(\mathrm{CH})$ (d/8 measurement geometry, with measurement wavelength range from $400 \mathrm{~nm}$ to $700 \mathrm{~nm}$ and measurement area of $20 \mathrm{~mm}$ ). Reflection measurements were calculated with the help of Datacolor Datamaster $(\mathrm{CH})$ Software resulting in CIE tristimulus values $X Y Z, L^{*} C^{*} h$ CIELAB 1976 and colour differences $d E^{*}$ according to [17].

The washing performance $q$ was calculated in accordance with [13]. The reference laundering procedure was performed in a Wascator FOM 71CLS Electrolux (S) under the following conditions: $5 \mathrm{~kg}$ cotton ballast load, stain strips, "Cotton Normal" washing programme (main washing, four rinsing phases), laundering temperature $40^{\circ} \mathrm{C}$, bath ratio $1: 5$.

The Cleaning performance index $C P I_{d E}{ }^{*}$ was calculated based on [18].

\section{Determination of secondary laundering effects}

The ballast load and SC fabric were laundered 25 times in a household washing machine according to the selected laundering procedure. Dimensional change, stiffness, decrease in breaking strength, incineration residue and colour characteristics were determined later.

The conditioned unwashed and 25 times washed standard fabrics were subjected to dimensional change and stiffness measurements, which were evaluated according to [19-20] methods. The breaking strength and incineration residue of unwashed and washed samples of standard fabric were determined by the [21-22] methods, respectively. The colour characteristics were determined by measuring reflection values and calculations of CIELAB values and $\mathrm{CIE}$ whiteness indexes $\mathrm{WI}_{\mathrm{CIE}}$.

The methodology for determining the secondary laundering effects has been described briefly in earlier studies [23-24].

\section{RESULTS AND DISCUSSION}

Five different household laundering procedures, the classical and with ozone combined procedure, were carried out regarding primary and secondary laundering effects. The characteristics of the used stain test strips and the structure of tested procedures are shown in tables 1 and 2 . The measured parameters of the performed one- and two-bath laundering procedures are presented in table 3, whilst the results of the primary and secondary laundering effects are shown in figures 1 and 2.

It is evident from table 3 that the washing performance indices are equal for procedures $\mathrm{CO}_{\mathrm{Rl}}$ and $\mathrm{CL}$ $(q=1.097)$, while somewhat higher washing performance differences occur for the procedure $\mathrm{CO}_{\mathrm{MR}}$ (diff. 0.0042 units) compared to the classical laundering procedure $\mathrm{CL}$. The lower washing performance index of procedure $\mathrm{CO}_{\mathrm{MR}}$ can be explained by the reaction between the ozone in the inlet water and detergent ingredients starting in the dosing vessel of the household laundering machine. It is known that ozone is an unstable molecule that decomposes spontaneously by a complex mechanism, thus generating hydroxyl free radicals which react with organic and inorganic compounds [16]. Dissolution of detergent in water raises the $\mathrm{pH}$ of the laundering bath, and, consequently, accelerates the generation of free radicals and, thus, decomposition and lower ozone concentration in the water. [25] found that the simultaneous use of ozone and some surfactants can even cause a decrease in detergency compared to the one achieved with the surfactant alone. This observation was attributed to the degradation of this surfactant in the presence of ozone. 


\begin{tabular}{|c|c|c|c|c|c|c|c|}
\hline \multirow{2}{*}{\multicolumn{2}{|c|}{ Parameter }} & \multirow{2}{*}{ Unit } & \multicolumn{5}{|c|}{ Laundering procedure } \\
\hline & & & CL & $\mathrm{CO}_{\mathrm{MR}}$ & $\mathrm{CO}_{\mathrm{RI}}$ & $\mathrm{PO}_{30}$ & $\mathrm{PO}_{40}$ \\
\hline \multicolumn{2}{|l|}{ WPI q } & 一 & 1.097 & 1.093 & 1.097 & 1.022 & 1.100 \\
\hline \multicolumn{2}{|c|}{ Cycle duration } & $\min$ & 111 & 117 & 119 & 105 & 119 \\
\hline \multirow{5}{*}{ Water } & $\mathrm{PW}$ & $\mathrm{L}$ & 一 & 一 & 一 & 13.69 & 13.74 \\
\hline & $\mathrm{MW}$ & $\mathrm{L}$ & 22.18 & 21.73 & 22.06 & 7.32 & 7.26 \\
\hline & $\mathrm{RI} 1$ & $\mathrm{~L}$ & 19.97 & 20.14 & 20.54 & 16.17 & 15.39 \\
\hline & $\mathrm{RI} 2$ & $\mathrm{~L}$ & 20.32 & 21.30 & 20.90 & 一 & - \\
\hline & SUM & $\mathrm{L}$ & 62.47 & 63.17 & 63.50 & 37.18 & 36.40 \\
\hline \multirow{2}{*}{ BR } & PW & 一 & 一 & 一 & 一 & $1: 3$ & $1: 3$ \\
\hline & $\mathrm{MW}$ & $1: 5$ & $1: 5$ & $1: 5$ & $1: 5$ & $1: 5$ & $1: 5$ \\
\hline \multicolumn{2}{|l|}{ RWC } & $\%$ & 63.66 & 64.40 & 66.33 & 63.25 & 66.59 \\
\hline \multicolumn{2}{|l|}{ Energy } & $\mathrm{kWh} / \mathrm{kg}$ & 1.054 & 1.050 & 1.026 & 0.406 & 0.867 \\
\hline
\end{tabular}

Note: WPI - Washing Performance Index, PW - Pre-Washing, MW - Main-Washing, RI1, RI2 - Rinsing, BR - Bath Ration, RWC - Remaining Water Content

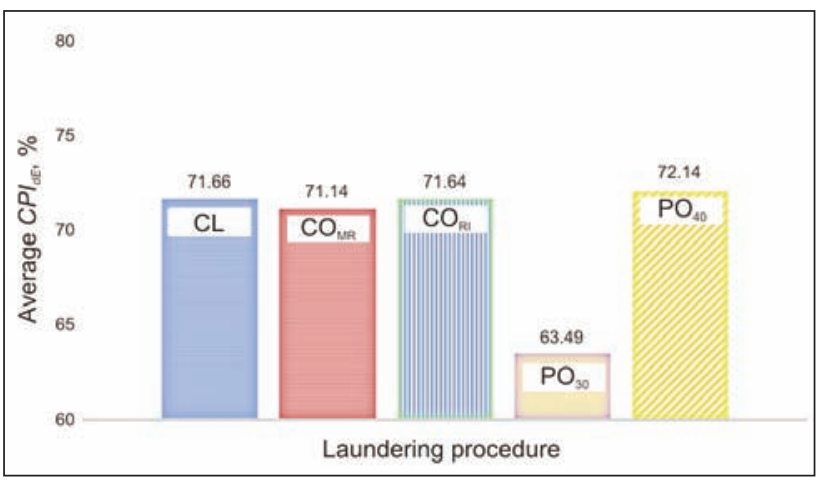

Fig. 1. Average Cleaning Performance Indices $C P I_{d E^{*}}$ of laundering procedures

From the results shown in table 3 , it can be noticed that the $\mathrm{CO}_{\mathrm{MR}}$ and $\mathrm{CO}_{\mathrm{Rl}}$ laundering cycles last longer (6 and $8 \mathrm{~min}$ ); concurrently the increased water consumption, whereas the electricity consumption declined compared to the classical procedure CL. Increased total water consumption in ozone laundering procedures is accordant with [26]. It has been reported that the increase in water absorbency of the ozonised samples is assumed to occur as a result of the oxidation of the hydrophobic impurities by ozonation [27]. Another hypothesis is that this phenomenon happens due to oxidation, which weakens the amorphous regions of the fibres, hence the liquid can find its way to be easily transported through [15].

In terms of efficiency as well as environmental impact, the two-bath ozone laundering $\mathrm{PO}_{30}$ and $\mathrm{PO}_{40}$ procedures (table 3 ) are in the foreground. With regard to the $C L$ process, the washing performance of the low temperature procedure $\mathrm{PO}_{30}$ is noticeably lower $(6.83 \%)$, while for procedure $\mathrm{P}_{40}$ it is surprisingly even higher in absolute values. Realization of the $\mathrm{PO}_{30}$ procedure demands $40.49 \%$ less water and 61.50 less energy compared to the classical laundering procedure, whilst the one of procedure $\mathrm{PO}_{40}$ demands $41.74 \%$ less water and $17.75 \%$ less electric energy. The cause for the lower energy efficiency

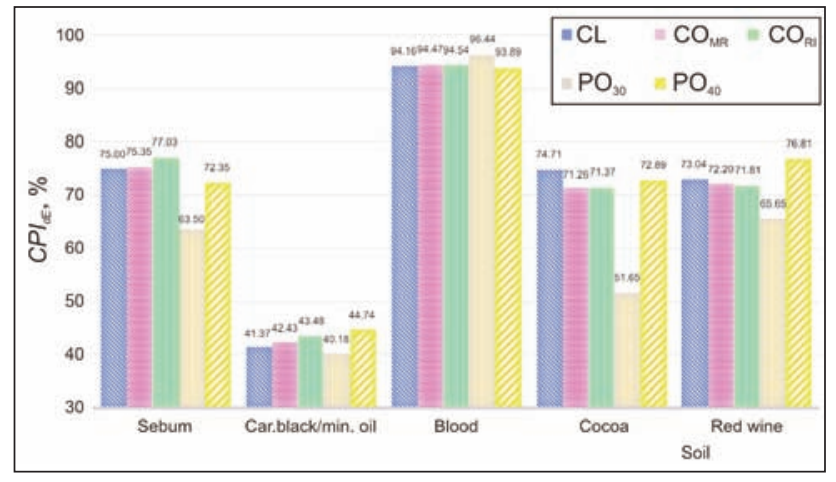

Fig. 2. Soil removal efficiency as $C P I_{d E^{\star}}$ of laundering treatments

of procedure $\mathrm{PO}_{40}$ is the laundering bath heating in the main-washing phase, which influences lower electricity saving and longer duration (119 $\mathrm{min}$ ) of the procedure $\mathrm{PO}_{40}$.

From the results of soil removal efficiency shown in figure 1 , one can summarise that the two-bath ozone laundering procedure $\mathrm{PO}_{40}$ removes, on average, the highest amount of stains $(72.14 \%)$, followed by procedures $\mathrm{CL}(71.66 \%), \mathrm{CO}_{\mathrm{RI}}(71.64 \%), \mathrm{CO}_{\mathrm{MR}}$ $(71.14 \%)$, and, at the end, the procedure $\mathrm{PO}_{30}$ with the lowest average $C P I_{d E^{*}}(63.49 \%)$. It was found that the most efficient removal (figure 2) for all ozone procedures, on average, was noted for pig's blood $(94.83 \%)$, followed by moderate soil removal of synthetic sebum $(72.06 \%)$, red wine $(71.62 \%)$ and cocoa (66.79\%), while for carbon black and paraffin oil soil the removal efficiency was noticeably lower $(42.71 \%)$. The low soil removal efficiency of the mentioned procedure could be attributed to the low temperature during the main-washing phase $\left(30^{\circ} \mathrm{C}\right)$ and the after-effect of inactivation of the system of bleaching agent SPB and bleach activator TAED [28].

Analyses of the primary laundering show that the household ozone laundering procedure $\mathrm{PO}_{40}$ provides the best results: highest washing performance and, at the same time, the lowest water and energy 


\begin{tabular}{|c|c|c|c|c|}
\hline \multirow{2}{*}{\multicolumn{2}{|c|}{ Parameter }} & \multirow{2}{*}{$\begin{array}{c}\text { Unwashed } \\
\text { standard fabric }\end{array}$} & \multicolumn{2}{|c|}{ Laundering procedure } \\
\hline & & & Classical (CL) & Ozone $\left(\mathrm{PO}_{40}\right)$ \\
\hline \multicolumn{2}{|l|}{ Dimensional change (\%) } & - & -13.35 & -10.25 \\
\hline \multicolumn{2}{|l|}{ Stiffness $\left(\mathrm{cN} \cdot \mathrm{cm}^{2}\right)$} & 6.14 & 4.86 & 5.08 \\
\hline \multirow[t]{2}{*}{ Breaking strength } & $F_{25}(\mathrm{~N})$ & 999.41 & 909.57 & 932.91 \\
\hline & $Z_{25}(\%)$ & - & 8.99 & 6.65 \\
\hline \multicolumn{2}{|l|}{ Incineration residue (\%) } & 0.0219 & 0.1158 & 0.1044 \\
\hline \multirow{6}{*}{$\begin{array}{l}\text { Colour characteristics } \\
\text { (D65/10) }\end{array}$} & $R_{460}$ & 76.57 & 88.22 & 90.57 \\
\hline & $Y$ & 78.74 & 82.95 & 83.57 \\
\hline & $L^{*}$ & 91.11 & 92.99 & 93.26 \\
\hline & $C^{*}$ & 2.90 & 2.37 & 3.05 \\
\hline & $h$ & 104.66 & 278.55 & 266.64 \\
\hline & $W I_{C I E}$ & 65.51 & 93.55 & 97.55 \\
\hline
\end{tabular}

consumption. These were the deciding factors in the ozone $\mathrm{PO}_{40}$ procedure being selected and carried out in investigation of secondary laundering effects. Table 4 shows the characteristics of standard cotton fabric washed 25 times in the classical or ozone procedures.

The results show that the dimensional change of fabric laundered in the classical procedure was noticeably higher $(13.35 \%$ shrinking) compared to ozone laundering $\mathrm{PO}_{40}$ (10.25\% shrinking). Classical laundering caused a higher change in fabric stiffness values (by $20.84 \%$ ) than laundering with ozone (by $17.28 \%)$, compared to the un-washed fabric. Moreover, the breaking strength $F_{25}$ of a fabric laundered classically 25-times was lower (diff. $89.84 \mathrm{~N}$ ) than ozone laundering (diff. $66.5 \mathrm{~N}$ ) compared to the breaking strength of the un-washed fabric. This also reflected in a decrease in breaking strength $Z_{25}$ and, thus, mechanical damage. In the case of ozone treatment, the value $Z_{25}$ was considerably lower $(6.65 \%)$ than in the classical procedure (8.99\%). These results can be explained by the fact that, after a certain amount of time, the ozone treatment deteriorates yarn tensile properties drastically, while the wickability increases simultaneously. The phenomena could be attributed to the weak links introduced in the fibre's amorphous region and their damage [15].

The results indicate a small difference in incineration residue between classically and ozone treated standard cotton fabric. However, the ash content of classical laundering was 5.2 times higher, and of ozone laundering 4.7 times higher, compared to the ash content of un-washed fabric. It is known that incrustation is caused by precipitation of calcium salts from hard water, together with the detergent ingredients, textile structure, washing and rinsing conditions (temperature, duration, bath ratio). During the laundering process accumulated incrustations in the textiles lead to soil retention, greying, fabric handle (higher stiffness values), mechanical damages, reduced absorbency, etc. [23, 29]. From the results of incineration residue we can conclude that repetition of ozone treatments obstructs the mineralization process of textiles during the laundering process.

Ozone oxidation potential and reduction of accumulated incrustations probably contribute to the colour characteristics and higher whiteness $W I_{C I E}$ of the $\mathrm{PO}_{40}$ process compared to the classical treatment CL.

\section{CONCLUSIONS}

Evaluation of the primary and secondary effects of classical and different household ozone laundering procedures was the main subject of the presented research. Procedures were performed with the help of a household laundering machine and commercial ozone-generator, while the laundering effect was evaluated with measuring equipment and methods which meet suitable Standards.

Results show that household ozone laundering provides higher soil removal efficiency and appreciable consumption of water and electricity, compared to the classical washing process.

The common characteristics of 25 time laundered standard cotton fabrics with ozone proved to be surprisingly good. We can conclude that laundering with ozone in a household drum washing machine causes lower damages to cotton fabric than the classical procedure.

However, the scope of further investigations will be the development of new ozone laundering processes, introduction of powerful ozone-generator and disinfection efficiency, but the first and foremost priority will be the improvement of additional security systems to prevent ozone escaping from the household machine into the surroundings.

\section{ACKNOWLEDGMENTS}

We are grateful to the Gorenje d.d. and OTRI ZT d.o.o. for the financial support of the project. We want to acknowledge Shelagh Margaret Hedges for the useful suggestions which she gave us during the origin of the presented article, and also for the final proof-reading. 


\section{BIBLIOGRAPHY}

[1] Scheid, F., Lambert, E., Maitra, W., Niestrath, M., Fäh, D., Portmann, C., Gorny, S., Stamminger, R. Textile quality depletion due to household machine wash - Ways to measure and impacts of wash duration and temperature on textiles. In: Tenside Surfactants Detergents, 2016, 53, pp. 438-444

[2] Fijan, S., Fijan, R., Šostar-Turk, S. Implementing sustainable laundering procedures for textiles in a commercial laundry and thus decreasing wastewater burden. In: Journal of Cleaner Production, 2008, 16, pp. 1258-1263

[3] Neral, B., Fijan, S., Šostar-Turk, S. Implementing sustainable laundering procedures for textiles in a commercial laundry and thus decreasing wastewater burden. In: Industria Textila, 2012, 63, 5, pp. 246-251

[4] Fonseca P, Almeida, A., Feilberg, N., Markogiannakis, G., Kofod, C. Characterization of the household electricity consumption in the EU, potential energy savings and specific policy recommendations. In: ECEEE Summer study, 2009, pp. 781-793

[5] Almeida, A, Fonseca, P., Schlomann, B., Feilberg, N. Characterization of the household electricity consumption in the EU, potential energy savings and specific policy recommendations. In: Energy and Buildings, 2011, 43, pp. 1884-1894

[6] Corina Moga, I., Pricop, F., Iordănescu, M., Scarlat, R., Dorogan, A. Quality monitoring for wastewater generated by the textile finishing. In: Industria Textila, 2013, 6, 4, pp. 222-228

[7] European Environment Agency. Energy efficiency and energy consumption in the household sector. Available form: http://www.eea. europa.eu

[8] Cardis, D., Tapp, C., DeBrum, M., Rice, G.R. Ozone in the Laundry Industry - Practical experiences in the United Kingdom. In: Ozone: Science in Engineering, 2006, 29, 2, pp. 85-99

[9] Global Energy Partners LLC. Operations evaluation report - Presurized Ozonation System-Final Report. In: Lafayette CA, 2006, pp. 11-13

[10] Rice, R.G., DeBrum, M. The ozone laundry handbook. In: Lulu, 2011, pp. 14-20

[11] Tapp, C. Ozone laundry, a detailed review of the method and science involved in a properly designed cold water wash ozone system. In: 46 th IDC Conference, WFK - Cleaning Technology Institute, 9 - 11 April 2013, Düsseldorf

[12] ISO 2267, 1986. Surface active agents - Evaluation of certain effects of laundering- methods of preparation and use of unsoiled cotton control cloth

[13] SIST EN 60456, 2010. Clothes washing machines for household use- Methods for measuring the performance

[14] Atav, R. Eco-friendly textile dyeing and finishing. 2014. Available from: http://www.intechopen.com/books/ecofriendly-textile-dyeingand-Finishing.pdf, 2014, pp. 10-15

[15] Maqsood, H.S., Wiener, J., Baheti, V., Eldeeb, M., Militky, J. In: Ozonation: a green source for oxidized cotton. In: Fibres \& Textiles in Eastern Europe, 2016, 24, 1(115), pp. 19-21

[16] Langlais, B., Reckhow, D.A., Brink, D.R. Ozone in drinking water treatment: Application and engineering. In: AWWARF and Lewis, Boca Raton FL, 1991, pp. 100-132

[17] CIE 15.3, 2004. Colorimetry - Colour of objects. Colour vision. Perception of colour

[18] Sutanto, S., Roosmalen, M.J.E., Witkamp, G.J. Redeposition in $\mathrm{CO}_{2}$ textile dry cleaning. In: Journal of Supercritical Fluids, 2013, 81, pp. 183-192

[19] SIST EN 25077, 2007. Textiles - Determination of dimensional change in washing and drying

[20] DIN 53362, 2003-10. Testing of plastics films and textile fabrics (excluding nonwovens), coated or not coated fabrics - Determination of stiffness in bending - Method according to Cantilever

[21] DIN EN ISO 13934-1, 2013-08. Textiles - Tensile properties of fabrics - Part 1: Determination of maximum force and elongation at maximum force using the strip method (ISO 13934-1:2013)

[22] ISO 4312, 1989. Surface active agents - Evaluation of certain effects of laundering - Methods of analysis and test for unsoiled cotton control cloth

[23] Fijan, S., Šostar Turk, S., Neral, B., Pušić, T. The influence of industrial laundering of hospital textiles on the properties of cotton fabrics. In: Textile Research Journal, 2007, 77, 4, pp. 247-255

[24] Lipuš, L.C., Ačko, B., Neral, B. Influence of magnetic water treatment on fabrics' characteristics. In: Journal of Cleaner Production, 2013, 52, pp. 374-379

[25] Jurado-Alameda, E., Miguel García Román, M.G., Vaz, D.A., Pérez J.L.J. Fatty soil cleaning with ozone and lipases - A way to develop more environmentally friendly washing processes. In: Household and Personal Care Today, 2012, 7, 4, pp. 49-52

[26] Eren, H.A., Ozturk, D. The evaluation of ozonation as an environmentally friendly alternative for cotton preparation. In: Textile Research Journal, 2011, 81, 4, pp. 512-519

[27] Prabaharan, M., Nayar, R.C., Kumar, N.S., Rao, J.V. A study on the advanced oxidation of a cotton fabric by ozone. In: Coloration Technology, 2006, 116, 3, pp. 83-86

[28] Dannacher, J.J. Catalytic bleach: most valuable applications for smart oxidation chemistry. In: Journal of Molecular Catalysis A: Chemical, 2006, 251, 1-2, pp. 159-176

[29] Anonymus. Laundering process control regarding gentle treatment. Evaluation of detergents and washing processes. In: Empa AG, 2003, pp. 10-14

\section{Authors:}

\section{BRANKO NERAL}

University of Maribor, Faculty of Mechanical Engineering,

Institute for Engineering Materials and Design, Maribor, Slovenia

\section{Corresponding author:}

Branko Neral

e-mail: branko.neral@um.si 